\title{
Review of Melvin Morse's Transformed by the Light
}

To the Editor:

I read with interest Robert Kastenbaum's (1993) review of Melvin Morse's book, Transformed by the Light (Morse and Perry, 1992), and Morse's (1993) response in the Journal to that review. My reading of Morse's book resulted in just the opposite conclusion from Kastenbaum: I found it to be an excellent work.

Kastenbaum's principal objection seemed to be that Morse included many anecdotal stories. Of course that is true, and of necessity has been true since the beginning of near-death research. The basic data for study must come from the stories of those who have undergone near-death experiences (NDEs), and to exclude the stories in an attempt to present some sanitized statistical version of the data would in itself be academically dishonest. By presenting stories as he did, Morse gave researchers the opportunity to analyze the information and generate their own statistical data base. Without the stories, there would be no data to analyze.

My own research for the book Echoes From Eternity (Gibson, 1993) showed that by being completely open to the anecdotal stories told me by NDErs, I left open the opportunity for new information from the participants. By this technique I was able to discern some completely new patterns that others had not yet reported on. Those patterns included several persons who saw themselves in a premortal environment (pp. 241-247). I included the complete anecdotal experiences so that other researchers can study my findings and can duplicate or reject the findings by further research in the same area.

Another criticism by Kastenbaum was Morse's claims to increased psychic powers by those having had NDEs, but the lack of hard scientific controls for verifying such claims. Again, one reason for the lack of such controls derives from the very nature of the psychic information being given to the recipients. Presumably such information is given-by some higher power-for the benefit of the recipient, and not so that the scientific community can verify its authenticity. Admittedly, much that is presented in the New Age world as psychic power can be shown to be fraudulent, but legitimate cases in the near-death literature abound.

In Echoes From Eternity I presented two startling cases in which individuals (Julie, pp. 50-61; and Eileen Pitcher, pp. 94-100) had re- 
markably detailed premonitions of events yet to occur in the future. In both cases I was able to verify the data by interviewing others who witnessed what subsequently transpired. Numerous other cases were also given in the book, but the verification was less rigid. One wonders what kind of control group could have been devised to verify Julie's story. By providing the complete details of the anecdotal stories, I at least allowed the reader to formulate his or her own judgment about the authenticity of the stories.

Kastenbaum objected to Morse's chapter entitled "The Glow of God." In my reading of Morse's two books-Closer to the Light (Morse and Perry, 1990) and Transformed by the Light (Morse and Perry, 1992)-I did get the impression that his understanding of the nature of the NDE has evolved with time, just as mine has. Morse seemed, in the more recent book, to have accepted a more ethereal cause for the NDE than in his first book. That also seems to be true of other researchers, such as George Ritchie, Raymond Moody, Kenneth Ring, and Maurice Rawlings. In his book The Light Beyond, Moody probably said it best in this manner:

For more than twenty years I have been working on the cutting edge of NDE research. In the course of my studies, I have listened to thousands of people tell about their deeply personal journeys into ... . what? The world beyond? The heaven they learned about from their religion? A region of the brain that reveals itself only in times of desperation?

I have talked to almost every NDE researcher in the world about his or her work. I know that most of them believe in their hearts that NDEs are a glimpse of life after life. But as scientists and people of medicine, they still haven't come up with "scientific proof" that a part of us goes on living after our physical being is dead. This lack of proof keeps them from going public with their true feelings .... .

I don't think science can ever answer that question. It can be pondered from almost every side, but the resulting answer will never be complete ....

In the absence of firm scientific proof, people frequently ask me what I believe: Are NDEs evidence of life after life? My answer is "Yes." (Moody and Perry, 1988, pp. 151-154)

I share Moody's perspective that it will never be possible to demonstrate "scientifically" a proof for life after death. My belief, however, is that NDEs do provide a glimpse of eternity, and that we are spiritual beings responsible to a God who created us. Our spiritual portion will continue after death in a breathtaking world more real than the one we are in now. I thank Morse for his insightful work, 
and encourage him to continue in this effort. He has helped many people gain a better understanding of the nature of death-and of life after life.

\section{References}

Gibson, A. S. (1993). Echoes from eternity. Bountiful, UT. Horizon.

Kastenbaum, R. (1993). [Review of Transformed by the light: The powerful effect of near-death experiences on people's lives]. Journal of Near-Death Studies, 12, 53-57. Moody, R. A., Jr., and Perry, P. (1988). The light beyond. New York, NY: Bantam.

Morse, M. L. (1993). Review of Transformed by the light and the progress of research [Letter]. Journal of Near-Death Studies, 12, 123-127.

Morse, M. L., and Perry, P. (1990). Closer to the light: Learning from the near-death experiences of children. New York, NY: Villard.

Morse, M. L., and Perry, P. (1992). Transformed by the light: The powerful effect of near-death experiences on people's lives. New York, NY: Villard.

Arvin S. Gibson

1412 E. Vineyard Drive Bountiful, UT 84010 